\title{
The Real-Life Experience of Visual Art in Czech Extracurricular and Co-curricular Education
}

\author{
By Zuzana Pechova*
}

\begin{abstract}
In 2016, the characteristics and approaches to art mediation as an educative approach to facilitation of understanding and experiencing art in Czech extracurricular field trips and school outreach programmes were defined and investigated by faculty members of Department of Primary Education within an independent research project. This paper presents a theoretical background to the investigation results. The research study used a qualitative research method of semi-controlled interviews with professionals from different extracurricular establishments. The goal was to achieve a holistic view of the current concept of visual art on the basis of extracurricular school programmes and their pedagogical potential and to describe and define the methodological specifics of this phenomenon using a research design based on datas gained from six extensive interviews The open-coding analysis method used here reveals a generalised view of the topic. Thus it will provide clear reasons and way of implementation of art mediation from extracullicular environment to schools.
\end{abstract}

Keywords: co-curricular education, extracurricular, experiential education, object-based education, Visual art.

\section{Introduction}

Educational systems worldwide are based on the idea of academic skills. The global economy is fuelled by innovation and creativity. Social discourse demands communication using images in addition to text (Duncan, 2012; Fulkova, Hajduskova, \& Sehnalikova, 2012). Therefore, visual art education is an important part of the school educational system. Yet, its importance worldwide is underestimated in the hierarchy of core subjects (Eisner, 2002; Kress, 2000).

Multiple research results prove positive outcomes from the effect of arts education on children's learning and development. Education through and in the visual arts produces positive learning outcomes, develops a sense of personal and cultural identity, supports socio-personal development and has a significant influence on cognitive development (Catterall, 2009; Bamford, 2006; Eisner, 2002; Fiske, 1999). Education is no longer associated only with classes, teachers or separated school subjects (Sobanova, 2012). Interdisciplinary education and that in arts are now required as part of learning about real-world issues. The real-life experience of art demands cooperation with the education community and with other institutions.

*Professor Assistant, Technical University of Liberec, Czech Republic. 


\section{Literature Review}

\section{Visual Art-Based Field Trip Activities and Outreach Programmes}

Extracurricular activities are defined as activities designed for school-aged young people to participate in learning activities outside of a standard curriculum (Bamford \& Wimmer, 2012). These co-curricular activities provide a channel for reinforcing lessons learned in the classroom offering students the opportunity to apply their academic skills in a real-world context, and are thus considered to be part of a well-rounded education (Massoni, 2011).

Visual art-based field trip activities (e.g. fine art gallery visit) and outreach programmes (e.g. an artist's workshop provided at school) are one of most frequently offered program of extracullicullar institutions for its potential of offering an encounter with artworks and resources not available at schools. They provide channels for reinforcing lessons learned in the classroom. These options offer students the opportunity to apply academic skills in a real-world context and give children a more direct, interactive experience of the arts (O'Brien \& Rollefson, 1995). Museums, community cultural institutions, art centres, artists and universities can become involved by providing art-based education programmes.

The first museum-provided educational programmes for schools and the origin of arts integration into other subjects took place in the U.S. (Wilson, 1997; Winslow, 1939). Art-based programmes are used in art education and are integrated into other subjects as one approach to teaching and learning that designates art as the primary pathway to learning. The emphasis on the educational value of arts and its connection with real-world issues is anchored in the Discipline Based Art Education (DBAE) approach (Basak, 2017). DBAE has expanded in other countries, and it has become a platform for the currently widespread Comprehensive Art Education approach, being an important approach for Czech art education.

In the Czech Republic, current art education curriculum documents and theories emphasise balance and cooperation between educational subjects and the community's involvement (Babyradova, 2007). There are four approaches to art education in Czech Republic. The art-centric approach is based on U.S. DBAE principles (Slavik, Hazukova, \& Samsula, 1997). Its actual development accents experiential attitudes of instruction (Babyradova, 2007), and thus the real-life experience of art outside the school (or brought to school) is highly desirable and very real.

\section{The Real-life Experience of Art Through its Mediation}

Object-based Education. The mediation of art is one way of perceiving artwork and facilitating its understanding. According to cuntructivism, the museum learning is seen as an active process (Hein, 1998; Hooper-Greenhill, 1999). The term "mediation of art" includes not only the work of pedagogues and lectors; it also covers publishing, art disclosure in media, exhibitions, fairs and other 
activities. In every locale and experience, there is always a piece of art present, even if only indirectly, for example, through its reproduction.

The real-life experience of visual art can be held through practical, experimental, mediating programmes called animations. The real-life experience of art is an essential precondition for the functional principles of animation, which is presented in the spirit of object-oriented learning (Horacek, 1998).

Object-based education and learning, or using objects for education, describes a partial method that supports gallery and museum education, for example. When it is not possible to work with a piece of art directly, an alternative object is used to facilitate the work - the interpretation and recognition of art. Object-based education is based on the idea that what is seen is more memorable than what is mediated only verbally (Chatterjee, 2010). This idea was already promoted by Comenius (Komensky, 1991). In most cases, the objects used in extracurricular and co-curricular programmes can be seen in natural settings and contexts; this aspect is often missing when working with art in school.

The Method of Animation as an Experiential, Creative, Educational Method of the Mediation of the Real-life Experience of Art. Animation is a broad term. Its interpretation is not clear, and the situation is made more difficult by the fact that its meaning is different in different countries and different languages. The Latin word "anima" means soul. The term "the animator" is more specific: one who gives life. Animation as an educational method within the real-life experience of art is called cultural animation (Siostrzonek, 2008). It incorporates gallery/ museum animation and the animation of cultural historical heritage.

Gallery/museum animation is a process involving contact with artwork. This process gives participants new possibilities of richer understanding and new experiences. Animation, therefore, adds the beautiful and irreplaceable element of effective practice to the cognition process. "Both thinking and learning get its tangible form" (Horacek, 1998, p.72).

Gallery/museum animation is a kind of accompanying programme for an exhibition institution called a mixed-method programme. It is a combination of a theoretical explanation or lecture and a practical part. During the theoretical part, a participant's role is passive and is that of receiving the information, while during the practical part, the participant is forced or encouraged to learn through an experience based on creative activities (Horacek, 1998). The practical part consolidates theoretical knowledge with enriching personal experience and reflection. The essence of the method of animation is therefore experimental and uses creative activity to work with art. These activities are a means to processes of natural learning.

The second type of cultural animation is the animation of historical heritage. This is viewed as one of the ways of caring for, presenting and popularising cultural historical heritage. It is mostly the tangible heritage of a country, region, city or a certain place. The animation of cultural historical heritage is more closely linked to methods of conservation, of cultural management and of art management. It is understood to be a method that works with the emotional side of its consumer. Animation is used in an interpretation programme as its motivating or experimental part. Just as with gallery/museum animation, there are conditional 
requirements for objects of heritage (Hicela \& Kuscevic, 2013). Example of such animation could be creative guided tours including drama and hand on activities organised by historical sites, museum, galleries, Non-Governmental organisations.

Existing research provide large scale of topics within the phenomenon of art mediation, object-based learning and the method of animation. However we found all the theoretic background fragmented into specialized topics with a lack of comprehensive view on intersections of its content and educative potential. It is therefore the research project was drawn up.

\section{Methodology of the Investigation of Approaches to Educational Programmes based on the Real-life Experience of Art out of the School Environment}

The interview research method was chosen to obtain data from an extracurricular environment. An interview is a form of questioning that allows us to obtain in-depth information and understand a problem more precisely, mainly because it requires personal contact with the respondent. It also enables the researcher to develop and influence the interview according to their needs.

This investigation consists of the analysis of six interviews conducted with experts from the Czech extracurricular establishment currently providing animation programmes to schools. Personal interviews were carried out over a period of four months. Each interview was recorded and then converted into text. The extracts of interview transcripts are part of the Findings, the respondents are coded as Respondent 1-6.

The aim of the interviews was a) to obtain data that are not available in the literature, are actual; b) to get a current view of how the Czech environment intersects with the animation of visual art outside the school.

The goal of the general interview guide approach was a) to obtain data for the analysis of an expert's personal subjective views on the current status of visual art animation in the extracurricular environment and b) to describe its learning potential and specific methodologies. To achieve our goal, we used a simple structure for the interview questions. We asked about the following:

1. The current status of visual art animation in extracurricular education,

- the ways of mediating cultural and historical heritage and animation,

- the definition of the concept of cultural and historical heritage and animation focused on specific field of interest of the respondent.

2. The pedagogical potential of visual art in extracurricular education,

- why/whether the cultural and historical heritage is valuable for education and for which field, subjects, thematic areas, key competencies,

- how does the respondent use the topics (and which exactly) of cultural historical heritage within the method of animation in his/her own practice. 
3. The methodological specifics of visual art mediation in extracurricular education,

- what makes the method of animation of cultural and historical heritage unique, compared to other ways of mediation and teaching methods,

- what are the disadvantages of the method of animation of cultural and historical heritage.

We conducted six extensive interviews at this stage of the research. Two interviews were conducted with a fine art gallery pedagogue, and one interview was conducted with each of the following: a lector of a historical monument, a leisure time animator, a university assistant professor and the founder of a nonprofit organisation engaged in the placement of artworks in public spaces. For capacity reasons, we present only the analysis results of the interviews. The presentation and citation of interviews is therefore missing.

The interviews were analysed to establish a system of categories to answer the research questions:

1. How is the method of visual art animation understood in real life and in professional practice?

2. What is the value and what are the characteristics of visual art animation in real life outside of school?

The method appropriate and chosen for collecting qualitative data was a purposive sampling, which focuses on particular characteristics of population that are in interest and will enable to answer given research questions. The type of purposive sampling best suiting our goals was the expert sampling, as the research needed to gain knowledge from peole with particular expertise. To avoid as much as possible the subjectivity and non-probability of unit selection, the counselling of non-involved faculty was used and 4 consultants from elementary school were gained by a snow-ball sampling method.

\section{Findings}

The collected data were processed by constant comparison and open coding. The aim of open coding is to create a categorised list of codes. The codes are further processed using an analytical strategy. The main goal of interview analysis is to try to understand how a person whose work is to mediate visual art in the extracurricular environment and school programmes views the topic. All respondents work with the animation method in their current work of art (in the form of an artwork or tangible or intangible cultural historical heritage).

The interviews were transcribed from audio recordings to digital text. The data were then processed using the paper and pencil method (Svaricek \& Sedova, 2007). The text was divided into units according to meaning. Codes were then assigned to each unit. As shown by Lee and Fielding (2004), each code is a word 
or a short phrase that captures a certain group of meanings. Each code can be distinguished in its content from others (Svaricek \& Sedova, 2007, p. 212).

Two main categories were created through the open coding of the first research question of: How is the method of visual art animation understood in real life and in professional practice?:

1. The dimensions of a work of animation

2. The ways of grasping the visual art in real life

The following categories were determined for the main category of animation dimensions:

Table 1. Open Coding for the Animation Dimension Category

\begin{tabular}{|l|l|}
\hline Category & Qualities \\
\hline \multirow{3}{*}{ Qualities of an animator } & Professionalism \\
& Active participation \\
& Flexibility \\
\hline \multirow{3}{*}{ Role of a participant } & Activity \\
& Personal deposit \\
& Internal will \\
\hline \multirow{3}{*}{ Nature } & Span \\
& Processability \\
& Creative activities \\
\hline \multirow{3}{*}{ Goal } & Enjoyment \\
& Communication \\
\hline & Meeting \\
\hline & Education for Art \\
& Facilitation \\
\hline
\end{tabular}

Visual art animation as an educational method includes certain dimensions that are divided among these categories. The dimensions represent the following:

1. The demands that animation requires from an animator

2. The demands that animation places on participants, whose role is fundamental to the functioning of the method

3. The specific means by which the educational goal of this method is achieved.

The content of this main category is expressed by the following text:

Animators are people who carry out animation with the participants, and if possible, they are authors of the programme. They are customarily teachers by profession-someone who is flexible and able to react spontaneously. The position of an animator is equal to that of the group participants. An animator is actively engaged and participates in programme activities. 
"The role of both the commentator and the guide is only to comment or to describe, to put the information into a context. But the animator, as well as the participants of animation, has to become a part of the story. Once he does not become a part of it, once he is not on the same frequency, he becomes just a guide."

Respondent 1. Personal interview. 25 April 2016

"Animator should be educated in pedagogy (unlike an actor or entretainer)...the best would be an education in leisure time pedagogy. I think it is important for him to be able to attract the participants, to entertain them well and to assure a quality output of the animation and interaction."

Respondent 3. Personal interview. 16 May 2016.

These findings shows the range of view on the profession of animator. There is a big amount of definitions or opinons on the quality needs of animator in Czech Republic differing in professional focus of author (Benes, 1980; Daniel, 2008; Juva, 2004; Jagosova, Juva, \& Mrazova, 2010; Sobanova, 2015).

Participants in animation are concerned and committed. They participate voluntarily in the programme.

Animation has no fixed form. There is a wide range of options for sharing information, experience and ways to shape or influence participants' education. Animation always emphasises both processual and creative activities.

"...the definition is extremely wide. But I would say that the gallery animation, pedagogy, or whatever we are going to call it, deals with the aducation towards the museum of gallery. And it complements art education in some ways."

Respondent 2. Personal interview. 3 February 2016

All respondents agreed on this width and thus confirm the fragmentation and variety of literature approaches.

Animation is based on experience as a route to knowledge. It is based on participants' communication with their groups, on their own work and on cooperation with the animator. It is based on their encounter with art, new horizons and new ideas. The goal of animation is art education and the facilitation of the process of learning. These findings could be enlarged by literature talking about this topic in a way, that art is here for your lives and encounter with art can be an enriching game (Daniel, 2008), animation help to rebuild the value system of participants (Horacek, 2006).

"Gallery or museum animation is an art mediation program, based on the principle of creative or expressive interpretation of the artefact. For me, animation is a performance place in which a group of participants represents art. It means the participant experiences art and learns through it, learns through artistic expression. I understand the animation as a story in time and space. I have come to the fact that the gallery animation is art education, it is a form of art pedagogy...and that is what I mean in the realization with any group of participants, it's not just professionals. This artistic communication lies in the key to unlocking the world. This key is the mediation of art."

Respondent 4. Personal interview. 15 September 2016 
The following categories were determined as being the main categories for ways to grasp visual art in real life:

Table 2. Open Coding for The Ways to Grasp Visual Art in Real Life

\begin{tabular}{|l|c|}
\hline Category & Qualities \\
\hline Multi-stratification & The basic element of culture \\
& Intangible heritage \\
Tangible heritage
\end{tabular}

The content for this main category is expressed by the following text:

The category of multi-stratification affects the breadth of perception of visual art in real life. It is most often seen in the context of tangible cultural historical heritage but also in the context of particular cultures. The understanding of cultural historical heritage as an essence of humans, who are a part of their culture, describes another particular dimension.

"The essence of cultural and historical heritage is a memory stored by mankind by those tangible and intangible monuments. Cultural and historical heritage is roots on which the whole culture and everything the men is part of, of should be part of, since the beginning of life. In its original meaning, the culture meant cultivation of the spirit, so men was a full men, in harmony of soul and body. That memory is the roots men could draw from it. It is not only the material part, but also spiritual."

Respondent 4. Personal interview. 15 September 2016

The avareness of respondents of the immense importance of cultural historical heritage is essential for the commitment for their work and anchored in professional discussion worldwide, as seen in recent research (Ocal, 2016; Hicela \& Kuscevic, 2013; Apostolopoulou, Covoeiras, \& Klorani, 2014).

"For me, cultural and historical heritage is probably public space and town in its whole, with all its aspects both tangible and intangible. It also means some genius loci, and not only tens and hundreds years old monuments, but also the new ones, including those not really nice. Its everything what makes a place unique, the less visible layers as well produced by people, tourist, residents."

Respondent 1. Personal interview. 25 April 2016

"Cultural and historical heritage is folklore, traditions, architecture, sculpture, art in public space. It is what originated on the basis of history, culture, tradition of a given locality, country, whether based on regional, national or European roots. It must be kept in order that it does not cease in globalisation, where the borders and limits are lost and we stop to perceive what is regional on national. We need to keep and 
maintain our heritage in order to not let it disappear. We need to keep our identity to know where our roots are, where do we come from...it is just so important."

Respondent 3. Personal interview. 16 May 2016

Cultural and historical heritage is a broad term. It is influenced by individual perceptions that we each have of the place, time and culture. The category of accessibility is descriptive and expresses a person's paths to cultural historical heritage.

1. The paths of an action take the form of animation, experimental programmes, art events, performances or workshops.

2. Then there are of course the classic routes such as tours, discussions, comments and lectures.

3. Finally, there are the impersonal paths in the form of the media, the printed word and so on.

One main category was created to answer the second research question:

1. What is the educational potential of visual art in real life?

The following categories were determined for the main category of animation dimensions and its qualities:

Table 3. Open coding for The Educational Potential of Animation of Cultural and Historical Heritage category

\begin{tabular}{|l|c|}
\hline Category & Qualities \\
\hline Difficulty/Demand & Material \\
& Psychical \\
& Time demanding \\
Contribution to school education & Organizational \\
\hline Motivation to care & Astray \\
Personal development & Accessibility \\
\hline Unconventional approach & Meeting \\
& Strengthening \\
\hline
\end{tabular}

The qualities of the first, quite descriptive category summarises the demands that may constitute a barrier to the transmission of cultural heritage, such as the need for a competent animator, finance, technology, equipment, supplies, materials, time, emotional stress and the importance of reflection.

"Animation is often considered as the degradation or art and history by professionals. Art and history seems to be very serious for them and the playful form of animation bothers them. And, of course, finance - animation is quite expensive even if it does 
not look like this. You need a lot of material aid, more people, you spend paper, colours, .... I think every castle should use animation as part of the programme offer. But it demands an effort...you often need some technique as well, you need to maintain it...."

Respondent 3. Personal interview. 16 May 2016

\begin{abstract}
"You need to have a partner for animation, the other side: the participants from who the engagement is required. Ideally when you get a participant from non-participant and when he engages the others in some action, consciously or unconsciously. We could, so to say, divide the metamorphosis of participant from non-recipient to recipient and at the end the transmitter. Which is ideal."
\end{abstract}

Respondent 1. Personal interview. 25 April 2016

The barriers mentioned above can be completed by those mentioned in literature, as insufficient communication between heritage and education political sectors, Lack of structural timing for cultural heritage education within present school systems (Culture et Démocratie, 2009), failure to adequately disseminate good transferable examples past and present (Collard \& Witte, 2015).

The educational potential of animation of cultural historical heritage includes specific objects and skills where visual art in real life can serve as a source of education but also benefit from the specific qualities that make it interesting for education. It is the opportunity for direct work with the "object" of art, for a personal experience. The rapture from the conventional environment of a classroom and a school building plays out its importance as well. Last, it is the authority of an unknown or different lecturer, who can activate and motivate the participants to learn.

\footnotetext{
"At least, the meeting with original artwork is unique. Extraordinary and irreplaceable is also the environment of the gallery because children are educated directly in the environment of the gallery, right on place, inside of the show, in front of real piece of art....To take kids out of the school environment is enormous advantage. The kids do not take the process as education, when being somewhere else. The education becomes fun, leisure time activity, even when you use some of the typical school educational approaches. This is probably such a basic advantage. And other benefits, again, meeting art, as such. Also, interactivity is a huge advantage. Our programmes are based on the fact that children not only hear something, they also try it. In the meantime they can use it, do hand on things, play some games or demonstrate something."
}

Respondent 2. Personal interview. 3 February 2016

Visual art as a part of heritage is a part of each of us and of our identity. Its knowledge influences our attitude towards it. The potential for visual art mediation may arise from the first real, conscious encounter with its content. This is the moment that may initiate the creation of art with a sense of belonging and a responsibility towards culture, community or cultural historical heritage.

"The advantage is the action, the perfomativeness of the whole action. It has the ability to draw the kids into the process, and they naturally encounter both the 
information and the experience of the meaning of that information or knowledge, experience. And cultural and historical heritage becomes a part of life in a natural way. It is not just theory, but something that they themselves have experienced, so there is a relationship to it and they will carry on. They are interested ... The contribution of the artistic communication, which takes place in art mediation projects: for at least one moment, the artist creates, according to the means of expression, art that gives him a different view of it and thing out of art. The participant passes through a certain transformation that makes his being in the contemporary world real and present. Or we can say that he is inspired on the path to selfawareness and that after the animation programme he should be somehow relaxed, restored. And, it may sound mystical, but I think it is the natural impact of art education."

Respondent 3. Personal interview. 16 May 2016

The personal development category expresses the effect of an encounter with visual art in real life on a participant. It touches its whole personality, its emotional, cognitive and conative competencies towards oneself and to others. This unconventional approach consists of action and includes moving, performativity, participation, experience, innovative means of expression, the need for a voluntary approach and playfulness.

"The uniqueness of animation of the cultural and historical heritage consists of a work with an experience in the sense that it takes it seriously, as the basis of education. Programically, it deliberately works with the affective domain and can use the methods that work. It develops the creativity of people, encourages people to create. Helps people cultivate their emotions if it is done well. It learns to hear and respect each other."

Respondent 6. Personal interview. 25 March 2016

In next phase of evaluation the axial coding was processed. Axial coding (Introduction to Grounded Theory) is the process of relating codes (categories and properties) to each other, via a combination of inductive and deductive thinking. To simplify this process, rather than look for any and all kind of relations, grounded theorists emphasize causal relationships, and fit things into a basic frame of generic relationships. The frame consists of the following elements: 
Table 4. The Elements of Frame of Generic Relationships

\begin{tabular}{|l|l|}
\hline Element & \multicolumn{1}{c|}{ Description } \\
\hline Phenomenon & $\begin{array}{l}\text { The concept that holds the bits together. In grounded theory it is } \\
\text { sometimes the outcome of interest, or it can be the subject. }\end{array}$ \\
\hline Causal conditions & $\begin{array}{l}\text { Events or variables that lead to the occurrence or development of the } \\
\text { phenomenon. It is a set of causes and their properties. }\end{array}$ \\
\hline Context & $\begin{array}{l}\text { The specific locations (values) of background variables. A set of } \\
\text { conditions influencing the action/strategy. } \\
\text { Researchers often make a quaint distinction between active variables } \\
\text { (causes) and background variables (context). }\end{array}$ \\
\hline $\begin{array}{l}\text { Intervening } \\
\text { conditions }\end{array}$ & $\begin{array}{l}\text { Moderating variables and intervening conditions } \\
\text { with } \text { mediating variables. }\end{array}$ \\
\hline Action strategies & $\begin{array}{l}\text { The purposeful, goal-oriented activities that agents perform in response to } \\
\text { the phenomenon and intervening conditions }\end{array}$ \\
\hline Consequences & The consequences of the action strategies, intended and unintended. \\
\hline
\end{tabular}

Within the axial coding, the categories from open coding were processed and led to creation of new ones, introduced in the table below.

Table 5. The Axial Coding Categories

\begin{tabular}{|l|l|}
\hline Element & \multicolumn{1}{c|}{ Coding } \\
\hline Phenomenon & Functional animation of cultural and historical heritage \\
\hline Causal conditions & $\begin{array}{l}\text { Educational goals } \\
\text { Accessible and reviving opportunity to grasp the present work / object / } \\
\text { phenomenon }\end{array}$ \\
\hline Context & $\begin{array}{l}\text { Components of cultural and historical heritage } \\
\text { The relationship, role and participation of the animator and the participant }\end{array}$ \\
\hline $\begin{array}{l}\text { Intervening } \\
\text { conditions }\end{array}$ & $\begin{array}{l}\text { Ways of conceiving the mediation } \\
\text { Obstacles along the way. }\end{array}$ \\
\hline Action strategies & $\begin{array}{l}\text { Experience creativity } \\
\text { Live group process }\end{array}$ \\
\hline Consequences & $\begin{array}{l}\text { Motivation to care } \\
\text { Personal development }\end{array}$ \\
\hline
\end{tabular}

To explain the content of those new categories, next table shows how they relate to open coding.

Table 6. Open Coding Qualities in Axial Coding Categories

\begin{tabular}{|l|l|}
\hline Axial Coding Categories & Qualities from Open Coding Categories \\
\hline & $\begin{array}{l}\text { Qualities of an animator: professionalism, } \\
\text { active participation, flexibility } \\
\text { Role of a participant: activity, personal } \\
\text { Functional animation of cultural and } \\
\text { historical heritage }\end{array}$ \\
& $\begin{array}{l}\text { Multi-stratification: the basic element of } \\
\text { culture, intangible heritage, tangible heritage }\end{array}$ \\
\hline $\begin{array}{l}\text { Educational goals } \\
\text { Accessible and reviving opportunity to } \\
\text { grasp the present work / object / } \\
\text { phenomenon }\end{array}$ & $\begin{array}{l}\text { Goal: Education for Art, facilitation, } \\
\text { interpretation } \\
\text { Contribution to school education: Part of } \\
\text { school lesson, astray, accessibility }\end{array}$ \\
\hline $\begin{array}{l}\text { Components of cultural and historical } \\
\text { heritage }\end{array}$ & $\begin{array}{l}\text { Qualities of an animator: professionalism, } \\
\text { active participation, flexibility }\end{array}$ \\
\hline
\end{tabular}




\begin{tabular}{|l|l|}
\hline $\begin{array}{l}\text { The relationship, role and participation of } \\
\text { the animator and the participant }\end{array}$ & $\begin{array}{l}\text { Role of a participant: activity, personal } \\
\text { deposit, internal will } \\
\text { Multi-stratification: the basic element of } \\
\text { culture, intangible heritage, tangible heritage }\end{array}$ \\
\hline & $\begin{array}{l}\text { Difficulty/Demand: material. Psychical. time } \\
\text { demanding, organizational } \\
\text { Boundedness: consistency, borderline, } \\
\text { aesthetic effect } \\
\text { Accessibility: unconscious perception, } \\
\text { actions, classic, impersonal }\end{array}$ \\
$\begin{array}{l}\text { Obstacles along the way } \\
\text { Enconventional approach: activity, } \\
\text { interactivity } \\
\text { Live group process }\end{array}$ & $\begin{array}{l}\text { Nature: enjoyment, communication, meeting } \\
\text { Personal development: internal, external }\end{array}$ \\
\hline $\begin{array}{l}\text { Motivation to care (remain) } \\
\text { Personal development (remain) }\end{array}$ & $\begin{array}{l}\text { Meeting, strengthening } \\
\text { Internal, external }\end{array}$ \\
\hline
\end{tabular}

The axial coding leads to the development of paradigm model that shows the relations between the categories. Is shown in scheme 1, the categories are linked non-circularly and nonlineary.

Scheme 1. Paradigm Model

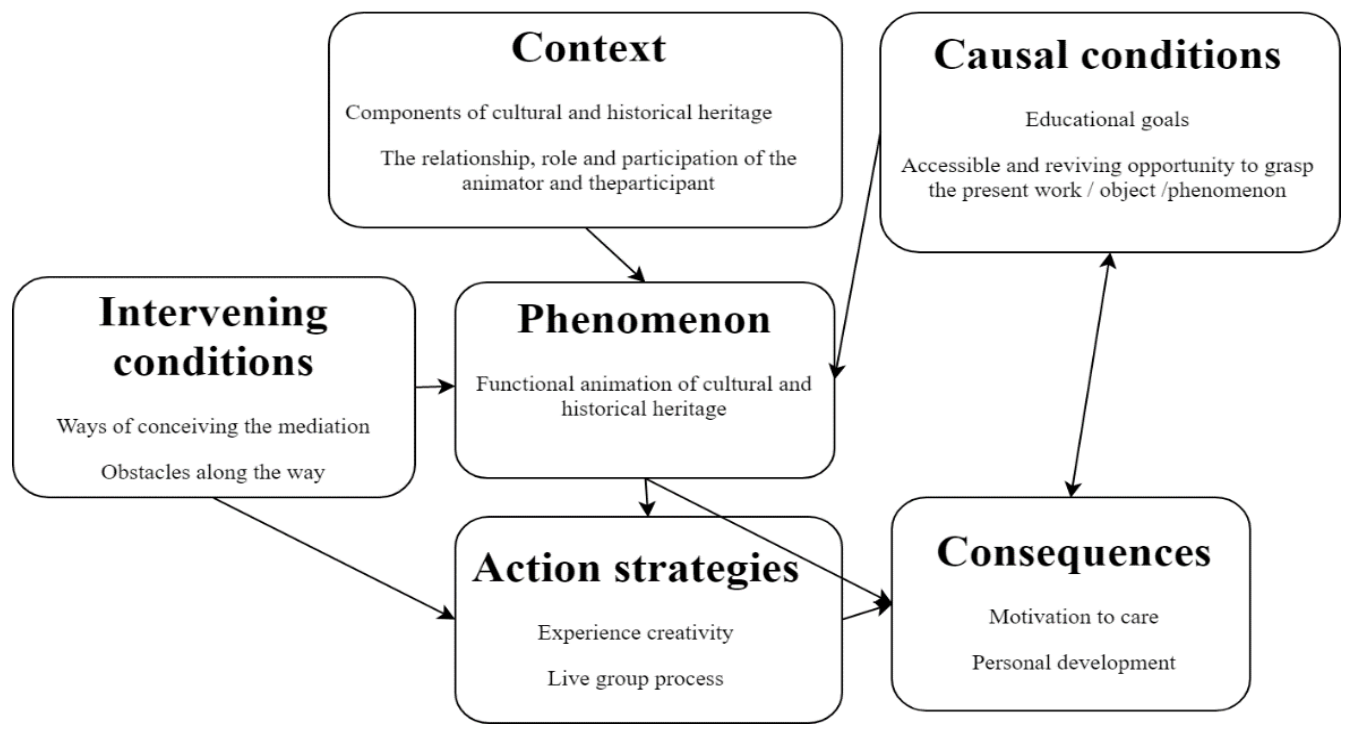

\section{Conclusions}

The Czech educational system requires connection and cooperation with school environments in its curricula documents. Although progress is visible, there is still a big gap between theory and practice. It is obvious from the results of our research study that the effort by extracurricular establishments and their lecturers to cooperate with schools shows a certain fragmentation and diversity in the approach to this phenomenon. 
The main statements summarizing the findings bring a concise view on the main research topics. The real-life experience of art outside of the school classroom in the Czech environment is understood as being an experiential, personal method. Instead of the position of teacher, the lecturer holds the position of partner or coordinator. The experience of art in an extracurricular environment is strongly related to historical heritage and its culture. The nature of this educational programme is best expressed with two basic principles: co-nativity and interactivity.

We believe that the concept of the mediation of the real-life experience of art as it is understood by extracurricular lecturers might become an opportunity for formal education as well (particularly art education). In accordance with existing curricula, these programmes could become an integral part of school education plans. Nowadays trends in Czech education strengthens the cooperation of schools and other institutions, but there is often a "free-time" reason for the participation, the teacher organizes an excursion, concert, museum visit as a supplementary program disconnected to current educational content of his lessons. And therefore there is a lack of preparation and continuing activities at school, that could link the contents of both school and out of school educational process.

The methodology using in depth interviews enables to get really personal information, direct and open approach of respondents secured acquisition of a large number of datas. However, the combination of multiple qualitative research methods could be useful, for example an observation of particularral programmes may bring clearer view on animators role and position in relation to participants or environment.

\section{References}

Apostolopoulou, A., Cavoeiras, L.M., \& A. Klonari, (2014). Cultural Heritage and education. In European Journal of Geography ,5(4), 67-77.

Babyradova, H. (2007). Nove proudy ve vytvarne vychove. In H., Babyradova, H., Grecmanova, \& P., Exler (eds), Skola muzejni pedagogiky 4 (pp. 9-24). Olomouc: Vydavatelstvi Univerzity Palackeho.

Bamford, A. (2006). The WOW factor: Global research compendium on the impact of arts in education. New York: Waxmann Munster.

Bamford, A., \&Wimmer, M. (2012). Audience building and the future Creative Europe Programme, EENC Short Report.

Basak, R. (2017). The Discipline-Based Art Education (DBAE) and the Visual Culutre Theory. Journal of Current Researches on Social Sciences, 7(4). Retrieved from https://bit.ly/2CoYlhG.

Benes, J. (1980). Muzeum a vychova. Praha: Ustav pro informace a rizeni v kulture.

Catterall, J. S. (2009). Doing Well and doing Good by Doing Art: The Effects of Education in the Visual and Performing Arts on the Achievements and Values of Young Adults. London: I-Group Books.

Chatterjee, H. (2010). Object-based learning in higher education: The pedagogical power of museums. Retrieved from https://bit.ly/2Fd3Q3q.

Collard P., \& Witte R. (2015). Creative Alliances for Europe, report prepared by the BkJ (Germany) and CCE (England) funded by Stiftung Mercator. 
Culture et Démocratie (2009). La culture au cœur de l'enseignement, un vrai défi démocratique. Cahier 2. Bruxelles: Communaute francaise de Belgique.

Daniel, L. (2008). Umění vidět umění: úvod do interpretace obrazu. Olomouc: Univerzita Palackého v Olomouci. ISBN 978-80-244-2000-4.

Duncan, A. (2012). It's March. Do you know How Strong Your Schools' Arts Programs Are? Retrieved from https://bit.ly/2W8VBMB.

Eisner, E. W. (2002). The Arts and the Creation of Mind. New Haven \& London: Yale University Press.

Fiske, E. B. (1999). Champions of Change - The Impact of the Arts on Learning. Washington, DC: The Arts Education and Partnership and the President's Comittee on the Arts and the Humanities.

Fulkova, M., Hajduskova, M., \& Sehnalikova L. (2012) Galerijni a muzejni edukace 1: vlastni cestou k umeni: vzdelavaci programy Umeleckoprumysloveho musea v Praze a Galerie Rudolfinum v roce 2011. Praha: Univerzita Karlova.

Hein, G. E. (1998). Learning in the museum. London: Routledge.

Hicela I., \& Kuscevic, D. (2013). School and the cultural-heritage environment: pedagogical, creative and artistic aspects. CEPS Journal, 3(2), 29-50.

Hooper-Greenhill, E. (1999). Education, communication and interpretation. In E. HooperGreenhill (ed.), The Educational Role of the Museum (2 ${ }^{\text {nd }}$ ed.), ( pp. 3-27). New York: Routledge.

Horacek, M. (2006). Galerijni pedagogove: klicnici rise krasy. Literarni noviny, 17(23), 915.

Horacek, R. (1998). Galerijni animace a zprostredkovani umeni. Brno: CERM.

Jagosova, L., Juva, V., \& Mrazova L. (2010). Muzejní pedagogika: metodologické a didaktické aspekty muzejní edukace, 1. ed. Brno: Paido.

Juva, V. (2004). Detske muzeum: edukacni fenomen pro 21. stoleti. Brno: Paido, Edice pedagogicke literatury.

Komensky J. A. (1991). Velka didaktika. Prel. M. Okal. Bratislava: SPN.

Kress, G. (2000). Multimodality. In B. Cope \& M. Kalantzis (eds.), Multiliteracies: Literacy learning and the design of social futures. Melbourne: Macmillan.

Lee, R., \& Fielding, N. (2004). Tools for qualitative data analysis. In M. Hardy, \& A. Bryman, Handbook of data analysis (pp. 530-546). SAGE Publications, Ltd doi: 10.4135/9781848608184

Massoni, E. (2011). Positive Effects of Extra Curricular Activities on Students. In ESSAI, 9, Article 27 (Jan. 2011). Retrieved from https://bit.ly/2CrimDY.

Ocal, T. (2016). Necessity of Cultural Historical Heritage Education in Social Studies Teaching. Creative Education, 7, 396-406. http://dx.doi.org/10.4236/ce.2016. 73039.

Siostrzonek, J. (2008). Animace kultury (polské inspirace). Opava: Slezská univerzita v Opavě.

Slavik, J., Hazukova, H., \& Samsula, P. (1997). Vytvarna vychova a jeji teorie v ceskych zemich ve svetovych kontextech. Praha: Pedagogicka fakulta UK.

Sobanova, P. (2012). Muzejni edukace. Olomouc: Univerzita Palackeho v Olomouci.

Sobanova, P. (2015). Vzdělávací obsah v muzejní edukaci. Olomouc: Univerzita Palackého v Olomouci. 2015.

Svaricek, R., \& Sedova, K. (2007). Kvalitativni vyzkum v pedagogickych vedach. Praha: Portal.

Wilson, B. (1997). The Quiet Revolution: Changing the Face of Arts Education. Los Angeles: The Getty Institute for the Arts.

Winslow, L. L. (1939). The Integrated School Art Program. New York; London: McGraw-Hill Book Company. 
